\title{
ACTIVITIES FOR FOSTERING DISABILITY AWARENESS AND FRIENDSHIP IN INCLUSIVE SCHOOL
}

\author{
Ossy Firstanti Wardany ${ }^{1}$, M. Furqon Hidayatullah' ${ }^{2}$ Wagimin $^{3}$ \\ ${ }^{1}$ Department Of Special Education, Graduated School, Sebelas Maret University,Surakarta, Indonesia \\ ${ }^{2}$ Department Of Physical Education And Sport Science, Sebelas Maret University, Surakarta, Indonesia \\ ${ }^{3}$ Department Of Guidance And Counseling, Sebelas Maret University, Surakarta, Indonesia
}

\begin{abstract}
Fostering disability awareness is important to improve peer acceptance and friendship between students with special needs and regular students. This study is a narrative review of previous research on activity for fostering disability awareness. We reviewed 16 studies that fit the criteria that we found on Eresources National Library of Indonesia. We find some activity to build awareness, namely, reading books about disability, peer network strategy, thematic intervention, puppets show, drawing comics, simulation, play intervention and sports activities. These activities can be references for teachers to improve acceptance and friendship in inclusive schools.
\end{abstract}

Keywords: disability awareness, friendship, inclusive school, activities

\section{INTRODUCTION}

Inclusive education is one of the topics discussed in the education world, including in Indonesia. Indonesia regulates inclusive education in the Decree of the Minister of Education and Culture No. 70 of 2009 on the implementation of inclusive education. In addition, the Act of The Republic of Indonesia Number 8 The year 2016 on People with disability article 10 affirms the right for children with special needs to learn, in special schools or inclusive schools. Every year the number of inclusive schools increased. In 2013, there are 2,603 inclusion schools in Indonesia with 46,783 students with special needs (Antara News Sumbar, June 22, 2013).

In 2016, inclusion schools in Indonesia increased to 31,724 schools with 159,001 students with special needs (Tempo.co, September 22, 2017). The growing quantity of inclusion schools should be followed by improved quality of inclusive education.

Inclusion refers to the practice of

* Corresponding author: Ossy Firstanti Wardany ossyfirstan@gmail.com

Published online at http://IJDS.ub.ac.id/2018

Copyright (C) 2018PSLD UB Publishing. All Rights Reserved special education services in regular classroom (Osborne, 2008). Friend \& Shamberger (2008) stated that inclusive is not a new label that describes where students sit on it. Inclusive education means of access to quality education for all children (Fiorella, Boyer, Thompson, 2008). It is means that every child has the right to get education, whatever their background. The notion of inclusive education has a particular relationship for Indonesia, whose national motto is 'Bhinneka Tunggal Ika' which means unity in diversity (Sheehy \& Budiyanto, 2015).

An inclusive society must consider what's best for each student and recognize that one size does not fit all (Tkachyk, 2013). Effective inclusion involves the sensitivity to and acceptance of individual strengths, challenges, and diversity (Salend, 2011). In an inclusive school, regular student can benefit from placement in inclusion programs, such as acceptance, understanding, and tolerance of individual differences and the development of meaningful friendships with classmates with special needs (Salend, 1999). Not only that, in students with special needs, inclusive school can provide opportunities for increased achievement, both socially and academically (Williamson, 2014). 
Roberts and Zubrick (1992) found that factors related to acceptance of students with special needs, namely academic achievement, teachers' perceptions and attitudes toward integration, peer perceptions and social status of student with special needs. It means that acceptance toward student with special needs influences their academic and social life in school. Konishi et al. (2010) said that interpersonal relationships within the school environment influence academic achievement. For example, poor relationships and bullying experiences can affect victims' academic achievement in both direct and indirect ways (Juvonen, et al., 2011). In addition, Student with special needs also often feel loneliness in school because they have few friends (Heiman 2000).

When students with special needs become students in inclusive schools, regular students do not automatically acceptance and making friendship with regular students student with special needs (McDougall, DeWit, King, Miller, \& Killip, 2004). That contact does not always have a positive impact on students' attitudes and some regular student does not want to have friends with student with special needs (Louari \& Paparousi, 2009).

Sometimes, regular students perceived student with special needs as playing mates, but they noted that limitations in communication (Lee, Yoo \& Bak, 2003). If student with special needs become aware of negative attitudes held by their peers, this can be detrimental to selfconfidence (Rillota \& Nettelbeck, 2007.

Attitudes of regular student relate to the social participation of students with disabilities (Boer, Pijl, Minnaert, 2012). If the attitude influences positive peer relationships and the formation of the friendships, then the inclusive school must have another tool for helping all children reach their full potential (Yu, Ostrosky \& Fowler, 2012) So it is important that regular students have a positive attitude towards students with special needs.

There needs to be an effort to increase the disability awareness and acceptance to increase friendship among students. These can be done by providing the knowledge and experience of disability Because of the lack of knowledge about disability can lead to feelings of discomfort and awkwardness (Litvack, Ritchie, \& Shore, 2011).
Awareness programs to be essential because they lead to positive attitudes towards students with special needs (Morin, Rivard, Crocker, Boursier \& Caron, 2008). The infusion of disability awareness programs into the general curriculum would represent a preventive approach to reduce the incidence of disabilities (Alves \& dos Santos, 2013). Awareness activities are a way to promote acceptance, understanding and increase knowledge about different disabilities (Ison et al, 2010; Rillota \& Nettelbeck, 2007). Disability awareness activities can addressing understands what means to live with disabilities and also accept individual differences (Alves \& dos Santos, 2013).

Teachers who have contact with a student in the classroom hold more positive attitudes towards inclusion of children with disabilities in their classes (Ahmmed, Sharma \& Deppeler, 2012). The way teachers interact with students 'influences students' behaviour and attitudes towards their peers with special needs (Cook, 2002). It can be said that teachers also have a role in building a positive attitude, including increasing the disability awareness of their students. It is important for teachers to improve student disability awareness. Teachers must have creativity and be active in helping students to accept each other's differences and make friendships with other friends. Teachers can do various ways to give students knowledge about disability and build friendship among students.

This research is a narrative review of previous academic papers. This narrative review aims to find some activities for teachers in inclusive schools to fostering disability awareness. We hope this article will help teachers in formulating activities to improve disability awareness and build friendships in inclusion classes.

\section{METHODS}

This study is a narrative review of the previous academic article about activities to promote disability awareness and making friendship with student with special needs. Wereviewed studies by searching in E-resources National Library of Indonesia, which subscribed the journals of ProQuest, Taylor \& Francis, EBSCO and Science Direct. The selected journal articles are articles of the last eight years, from February 2010 to February 
2018. We searched the studies in February 2018 using the keywords "disability awareness", "activities"," peer acceptance" ,"friendship", "attitude", "inclusive" and "program.

There are criteria for selecting articles, namely, (a) International journals, written in English; (b) Published within the last eight years (2010-2018); (c) About activities to fostering disability awareness or/and children with special needs; (d) In the form of a review study or experimental research; (e) Article available in full text (not just the abstract); (f) the research in inclusive school (limited to the school age). The academic article selected according to the criteria then reviewed and analyzed. Further, we constructed the activities that can use to fostering disability awareness and friendship in inclusive school.

\section{RESULT \& DISCUSSION}

Found some articles related to activities that fostering disability awareness. However, only 16 articles meet the criteria. Steps in selecting articles can be seen in Figure 1. The summary of the articles can be seen in table 1 .

\subsection{Type of activities}

\section{a. Reading Children Literature}

There are four studies that use reading books as an activity to increase disability awareness. Research by Wilkins, Howe, Seiloff, Rowan, and Lily (2016) aimed to explore the use of disability-themed children's books in third and fourth-grade students in South Carolina. Then, the three studies were review studies. Sigmon, Tackett \& Azano (2016) specifically reviewed picture books about autism and recommend read-aloud activities and discussions to build awareness, acceptance, and empathy for autistic children.

Artman-Meeker, Grant \& Yang (2016) review the children's book on disability contained in The Dolly Gray Awardees. The study recommended a variety of activities and questions that can be given to students after reading a book about disability according to the school level. There is also a guide for teachers how to choose the right book. Price, Ostrosky \& Santos (2016) reviewed two books on disability and presented some questions for teachers that could be used as rules in selecting books to teach about disabilities in kindergarten.

All of the studies have in common, that teachers should be careful when choosing a book to raise awareness. Not only that, activities after reading books such as discussion, role play or retelling are recommended for giving understanding and increasing peer acceptance. Reading aloud was advised to do for kindergarten and elementary school.

\section{b. Peer Network Strategy}

Peer network strategy is a strate-gy to build friendships and acceptance. There are two studies that use peer partners to build awareness and friendship towards students with special needs. One study is a narrative review and the other is a case study.

Carter, Asmus \& Moss (2013) suggests there are 3 strategies to improve friendship between student with and without developmental disability in high school. Namely, peer support arrangement, peer network strategy, and peer partner program. Furthermore, O'Connor's research (2016) is a case study using 'Circle of Friends' strategy to improve acceptance and friendship with autistic students in the classroom. 'Circle of Friends is a strategy which develops a support network of friendship around children who isolated (O'Connor, 2016).

From Keywords found 1256 article.

From title and abstract 31 studies met criteria and 1225 removed (irrelevant)

based on full text 15 articles removed ( 5 activities not in school, 9 unrelated and 1 duplicate)

In review 16 article

Figure 1. The Process of Selecting Article 
Table 1. The Summary of the articles

\begin{tabular}{|c|c|c|c|c|}
\hline No & Authors & Activity & $\begin{array}{l}\text { Type of } \\
\text { disability }\end{array}$ & $\begin{array}{l}\text { Age or the school } \\
\text { level }\end{array}$ \\
\hline 1. & $\begin{array}{l}\text { Artman-Meeker, } \\
\text { Grant \& Yang } \\
(2016)\end{array}$ & $\begin{array}{l}\text { Using literature with } \\
\text { discussion }\end{array}$ & $\begin{array}{l}\text { Various kind of } \\
\text { disability }\end{array}$ & $\begin{array}{l}\text { Preschool, primary } \\
\text { school, middle to } \\
\text { high school }\end{array}$ \\
\hline 2. & Seidler (2011) & Comics strips & $\begin{array}{l}\text { Disability in } \\
\text { general }\end{array}$ & Sixth-grade \\
\hline 3. & $\begin{array}{l}\text { Carter, Asmus, } \\
\text { Moss (2013) }\end{array}$ & $\begin{array}{l}\text { Peer Support and } \\
\text { peer partner program }\end{array}$ & $\begin{array}{l}\text { Developmental } \\
\text { disability }\end{array}$ & Teen (high school) \\
\hline 4. & $\begin{array}{l}\text { de Boer, Pijl, } \\
\text { Minnaert, Post } \\
\text { (2014) }\end{array}$ & $\begin{array}{l}\text { Intervention using } \\
\text { books, games, } \\
\text { drawing, etc in } 3 \\
\text { weeks. }\end{array}$ & $\begin{array}{l}\text { intellectual, } \\
\text { physical } \\
\text { and severe } \\
\text { physical and } \\
\text { intellectual } \\
\text { disabilities } \\
\end{array}$ & $\begin{array}{l}\text { Kindergarten and } \\
\text { primary school (4-12 } \\
\text { years) }\end{array}$ \\
\hline 5. & Dunst (2014) & Puppet show & $\begin{array}{l}\text { Disability in } \\
\text { general }\end{array}$ & Primary school \\
\hline 6. & O’Connor (2016) & $\begin{array}{l}\text { 'Circle of Friend' } \\
\text { strategy }\end{array}$ & $\begin{array}{l}\text { Asperger } \\
\text { syndrome }\end{array}$ & Ten years old \\
\hline 7. & $\begin{array}{l}\text { Lindsay \& } \\
\text { McPherson (2011) }\end{array}$ & $\begin{array}{l}\text { disclosure of } \\
\text { disability and } \\
\text { creating awareness, } \\
\text { building awareness of } \\
\text { bullying and building } \\
\text { a peer support } \\
\text { network }\end{array}$ & Cerebral palsy & $8-19$ years old \\
\hline 8. & $\begin{array}{l}\text { Hurst, Corning \& } \\
\text { Ferrante (2012) }\end{array}$ & $\begin{array}{l}\text { Disability-Simulation } \\
\text { Program }\end{array}$ & $\begin{array}{l}\text { physical, visual, } \\
\text { and learning and } \\
\text { auditory } \\
\text { disabilities }\end{array}$ & Elementary school \\
\hline 9. & $\begin{array}{l}\text { Moore \& Nettlebeck } \\
\text { (2013) }\end{array}$ & $\begin{array}{l}\text { Disability awareness } \\
\text { training }\end{array}$ & $\begin{array}{l}\text { Disability in } \\
\text { general }\end{array}$ & 13 years old \\
\hline 10. & $\begin{array}{l}\text { Nowicki \& Brown } \\
\text { (2013) }\end{array}$ & $\begin{array}{l}\text { "A Kid ways" a } \\
\text { thematic activities }\end{array}$ & $\begin{array}{l}\text { Learning or } \\
\text { intellectual } \\
\text { disability }\end{array}$ & $9-12$ years old \\
\hline 11. & O’Neill (2013) & Play intervention & $\begin{array}{l}\text { Social and } \\
\text { emotional } \\
\text { problem }\end{array}$ & Preschool \\
\hline 12. & $\begin{array}{l}\text { Price, Ostrosky \& } \\
\text { Santos (2016) }\end{array}$ & $\begin{array}{l}\text { Using children' } \\
\text { books }\end{array}$ & $\begin{array}{l}\text { Various kind of } \\
\text { disability }\end{array}$ & Kindergarten \\
\hline 13. & $\begin{array}{l}\text { Ranson \& Byrne } \\
(2014)\end{array}$ & $\begin{array}{l}\text { Autism Anti-Stigma } \\
\text { Program }\end{array}$ & autism & $7^{\text {th }}, 8^{\text {th }}, 9^{\text {th }}$ grades \\
\hline 14. & $\begin{array}{l}\text { Sigmon, Tackett \& } \\
\text { Azano (2016) }\end{array}$ & Picture books & autism & Elementary school \\
\hline 15. & Tindall (2013) & Sport & $\begin{array}{l}\text { Various kind of } \\
\text { disability }\end{array}$ & $\begin{array}{l}\text { 14-15 years old } \\
\text { (secondary school) }\end{array}$ \\
\hline 16. & $\begin{array}{l}\text { Wilkins, Howe, } \\
\text { Seiloff, Rowan, \& } \\
\text { Lily (2016) }\end{array}$ & Children literature & $\begin{array}{l}\mathrm{Va} \\
\text { rious kind of } \\
\text { disability } \\
\end{array}$ & Elementary school \\
\hline
\end{tabular}

\section{c. Thematic intervention}

Four studies are experimental studies (de Boer, Pijl, Minnaert, Post, 2014; Nowicki \& Brown, 2013; Moore \& Nettlebeck, 2013; Ranson \& Byrne, 2014) and one using interviews and focus group discussions (Lindsay \& McPherson, 2011).

Reseacher from de Boer et.al (2014) use intervention program to improve good attitudes of elementary school and kindergarten students 
towards students with intellectual, physical and severe physical and intellectual disabilities. de Boer et al using presentation and reading storybook for kindergarten, movies for elementary school and using group discussion and simulation too for all of them.

Nowicki \& Brown (2013) uses thematic intervention named 'A Kid Way which consists of seven themes. A kid way is a strategy of teacher intervention in academic and social situations, child-to-child instructional strategies, modelling appropriate behaviours and intervening in negative interactions and building supportive attitudes and accepting diversity in the classroom.

Moore \& Nettelbeck (2013) uses a disability awareness training program that includes guest speakers (athletes from the Paralympics and the Special Olympics), a documentary about people with disability, disability simulation activity, and factual information about different disabilities. Ranson $\&$ Byrne (2014) used The Anti-stigma Program to promote awareness and acceptance towards peers with higher-functioning autism. The Autism-Anti-Stigma program consists of five sense brainstorming, read aloud book about autism, discussion, online activities, do worksheet that followed explanation, watching video and invite guest speakers.

Lindsay \& McPherson (2011) conducted interviews and discussions with children with cerebral palsy, the discussion drafted a strategy to improve disability awareness and social inclusion, consisting of disclosure of conditions and creating awareness of disability, awareness of bullying activities, developing a peer support network and building self-confidence; and teacher support in the classroom. Thematic intervention usually consists of several sessions with a variety of fun activities with the aim of raising awareness and acceptance.

\section{d. Puppets Show}

Dunst (2014) studied research on the effectiveness of Kids on the block and Count Me On puppets show. This study is a metaanalysis of 26 previous studies on the use of puppets show to improve knowledge and attitude toward children with special needs. The results show that puppets show can improve attitudes and knowledge about disability in elementary school students. Although, puppets show was more influential on improving knowledge and understanding about disability than attitudes. Dunst (2014) recommends the use of puppets show and relate them to real life to improve the attitude towards special needs.

\section{e. Drawing comic}

Seidler (2011) increase the disability awareness and fighting disability stereotypes used comics strip. Seidler asked sixth grades students to create comics about disability as a project of art education. Before making comics, teachers and students discuss stereotypes that exist in people with special needs, why stereotype comes up and explore their experiences. Discussions after comic project also need to raise awareness and build a positive attitude.

\section{f. Simulation}

Hurst, Corning \& Ferrante (2012) use the Disability-simulation program, which is a program to increase disability awareness through simulation activities. In the Disabilitysimulation program, students are divided into small groups and they simulate they are children with physical disability, visual impairment, hearing impairment and a learning disability. By simulating themselves as children with special needs, children can put themselves in the 'shoes' of others. It can foster awareness, empathy, understanding and acceptance of students with special needs.

\section{g. Play Intervention}

O'Neill (2013) used play intervention techniques in an inclusive preschool class. Play intervention is an activity that adapts some games to improve social-emotional development and interaction among students in inclusion classes.

Play intervention can be activities that include all students to interact and communicate in the classroom through play activities. In this study, O'Neill uses dramatic play, games playgroup, invites other students to play along with students who play alone, nonverbal games and etc. It takes the teacher's sensibility and creativity to build games that can raise awareness and acceptance of friends in preschool.

\section{h. Sport activities}

Sport can be an activity that increases disability awareness and interaction with students with special needs. Tindall (2013) 
using a sit-volleyball as disability awareness activities. Students watch the video and get an explanation about the sit-volleyball game before. Sit-volley ball is an adaptive sport for students with special needs.

Through adaptive sports, students are expected to have experience in the adaptive sports for people with disabilities. Sports activities can be an option to raise awareness and build friendship, both in general sports and adaptive sports. Sports in groups also can encourage interaction, cooperation and sportsmanship in students.

\subsection{Learning Materials and Types of Disabilities}

In general, these studies teach about knowledge, attitude and behaviour toward disabilities. This is because increasing knowledge can affect attitude and behaviour. Five studies provided material disability in general (Seidler, 2011; Dunst, 2014; Moore \& Nettlebeck, 2013; Price, Ostrosky \& Santos, 2016; Tindall (2013), four studies taught a variety of disabilities (Artman-Meeker, Grant \& Yang , 2016; de Boer, Pijl, Minnaert, Post, 2014 ;Hurst, Corning \& Ferrante, 2012; Wilkins, et al., 2016). Then, each one study for Asperger syndrome (O'Connor, 2016), developmental disability (Carter, Asmus, \& Moss, 2013), Cerebral Palsy (Lindsay \& McPherson, 2011), intellectual disability (Nowicki \& Brown (2013), and social and emotional problems (O'Neill, 2013). Two studies about autism (Ranson \& Byrne 2014; Sigmon, Tackett \& Azano, 2016).

Teachers can provide materials regarding the concept of disability at the beginning of the program. Furthermore, the material is an introduction to the types of disability, how they characterize and how to behave towards them. Teachers may be able to introduce starting from the type of disability that is in the classroom. This not only gives knowledge but improves the acceptance of student with special needs in the class. The material needs to be well adapted to the age of the student.

\subsection{The Effectiveness and Duration of the Intervention}

There are seven studies that are action research and measure the effectiveness of a program or intervention. The research of de Boer, Pijl, Minnaert, Post (2014) indicates a positive outcome, although the effect on positive attitudes is greater in kindergarten students than in elementary school. Adaptive sports conducted Tindall (2013) have a positive impact on the attitude of students who follow the activity.

Furthermore, study from Ranson \& Byrne(2014) with Autism Anti-Stigma Program, Seidler (2011) with comics project, O'Connor (2016) with Circle of friends, Hurst, Corning \& Ferrante (2012) with simulation, O’Neill (2013) and Moore \& Nettlebeck (2013) with Disability awareness training, have all shown positive results to improve knowledge, attitudes, and behavior of students. It indicates that giving intervention can increase disability awareness.

The duration of each intervention varies. There are studies that do not mention the duration. The longest study duration was conducted by O'Connor (2016) within 3 months, 12 sessions with each 30-40 minutes/session. Research de Boer, Pijl, Minnaert, Post (2014) conducted for 3 weeks. Research Hurst, Corning \& Ferrante (2012) and also Moore \& Nettlebeck (2013) are both conducted during four meetings. O'Neill (2013) did intervention for 6 weeks, and Seidler (2011) for 7 meetings. Ranson \& Byrne (2014) and Tindal (2013) studies were conducted at 8 weeks or 8 sessions. The interesting thing is that generally, every session of the research takes between 30-50 minutes in every week. The duration of each intervention by previous research can be a reference for teacher.

Based on the results, we found some activities that can build acceptance and disability awareness. The results of this study show that there is a variety of education levels, from preschool to high school. This suggests that fostering disability awareness activities can be done at every level. Building awareness and acceptance of disability should be since studens in the preschool and continuous to the next level of education. The material must also match with their age and prior knowledge they had befofe.

Reading books about disability, peer network strategy, thematic intervention, puppets show, drawing comics, simulation, play intervention and sports activities are examples of activities to increase acceptance of disability. 
These activities can be part of the classroom learning. For example, reading a book about disability when learning literature or drawing comics about disability when art lessons. The preschool teacher can also enable monitoring and intervention to foster acceptance and friendship among all students. Simulation or thematic intervention activities can be given as a continuous extracurricular program for students in the higher/secondary school.

Results of previous studies show that activities that build disability awareness is effective for increasing disability awareness, acceptance and friendships toward student with special needs(de Boer, Pijl, Minnaert \& Post, 2014; Tindall, 2013; Ranson \& Byrne, 2014; Seidler, 2011; Hurst, Corning \& Ferrante, 2012; O'Neill, 2013; Moore \& Nettlebeck, 2013) .Teachers can do various things to raise awareness in inclusive schools. Material, duration of intervention, and duration of each session can be tailored to the needs and circumstances of the students.

\section{CONCLUSION}

Based on the results and discussion, there are various activities that teachers can do, such as reading books about disability, peer network strategy, thematic intervention, puppets show, drawing comics, simulation, play intervention and sports activities. When selection the activities for students, it must be suited to their age and their prior knowledge. Fostering disability awareness activities should be done early and become a sustainable activity from preschool to high school. Because of it is important to maintain and improve their acceptance. Teachers need to be creative and innovative to make fun activities to fostering disability awareness, peer acceptance, and building friendship.

\section{REFERENCES}

Ahmmed, M., Sharma, U. and Deppeler, J. (2012) 'Variables affecting teachers' attitudes towards inclusive education in Bangladesh'. Journal of Research in Special Educational Needs · 12(3). 132-140

Alves, S., \& dos Santos, P. L. (2013). Bringing disability awareness into the general curriculum. In Future directions: uncertainty and possibility: european conference on curriculum studies.

Antara News Sumbar (2013, 22 Juni). Jumlah Sekolah Inklusif Bertambah Dua Kali Lipat diperoleh pada 3 Maret 2018 dari https://sumbar.antaranews.com/berita/45350/ju mlah-sekolah-inklusif-bertambah-dua-kali-lipat Artman-Meeker, K., Grant, T. O., \& Yang, X. (2016). By the book: Using literature to discuss disability with children and teens. TEACHING Exceptional Children, 48(3), 151-158.

Carter, E. W., Asmus, J., \& Moss, C. K. (2013). Fostering Friendships: Supporting Relationships Among Youth With and Without Developmental Disabilities. Prevention Researcher, 20(2), 14-17.

Cook, B. G. and Semmel, M. I. (1999) 'Peer Acceptance of Included Students with Disabilities as a Function of Severity of Disability and Classroom Composition', The Journal of Special Education, 33(1), 50-61.

de Boer, A., Pijl, S. J., Minnaert, A., \& Post, W. (2014). Evaluating the effectiveness of an intervention program to influence attitudes of students towards peers with disabilities. Journal of Autism and Developmental Disorders, 44(3), 572-583.

Dunst, C.J. (2014). Meta-analysis of the effects of puppet shows on attitudes toward and knowledge of individuals with disabilities. Exceptional Children, 80(2), 136148.

Fiorello, C.A., Boyer, J.A., \& Thompson, R.J. (2008). Inclusion. In N. J. Salkind \& K. Rasmussen (Eds.), Encyclopedia of Educational Psychology (Vol. 2, pp. 508-511). Thousand Oaks, CA: SAGE Publications.

Friend, M. \& Shamberger, C.T. (2008). Inclusion. In T.L.Good (Ed.), 21st Century Reference Series. 21st Century Education: A Reference Handbook Vol. 2 (124-131). Thousand Oaks, California: SAGE Publications.

Heiman T. (2000) Friendship quality among children in three educational settings. Journal of Intellectual and Developmental Disability 25, 1-12.

Hurst, C., Corning, K., \& Ferrante, R. (2012). Children's acceptance of others with disability: The influence of a disability-simulation program. Journal of Genetic Counseling, 21(6), 873-883

Ison, N., McIntyre, S., Rothery, S., SmithersSheedy, H., Goldsmith, S., Parsonage, S., et al. 
IJDS 2018; Vol. 5 No. 1, May 2018, pp. 106-114

ISSN: $2355-2158$

(2010). 'Just Like You': A Disability Awareness Programme For Children That Enhanced Knowledge, Attitudes And Acceptance: Pilot Study Findings. Developmental Neurorehabilitation, 13, 360368

Juvonen, J. Wang, Y. \& Espinoza, G. (2011). Bullying Experiences and Compromised Academic Performance Across Middle School Grades. The Journal of Early Adolescence 31(1):152-173

Konishi, C., Hymel, S., Zumbo, B. D., \& Li, Z. (2010). Do school bullying and student teacher and academic achievement. Canadian Journal of School Psychology, 25(1), 19-39.

Lee, S., Yoo, S. and Bak, S. (2003) 'Characteristics of Friendships Between Children with and without Mild Disabilities', Education and Training in Developmental Disabilities, 38(2), 157-166

Lindsay, S., \& McPherson, A. C. (2012). Strategies for improving disability awareness and social inclusion of children and young people with cerebral palsy. Child: Care, Health \& Development, 38(6), 809-816

Litvack, M. S., Ritchie, K. C., \& Shore, B. M. (2011). High- and average-achieving students' perceptions of disabilities and of students with disabilities in inclusive classrooms. Exceptional Children, 77(4), 474-487.

Louari, M., Paparousi, M. (2009). Do children with disabilities have friends? In Ines Gomes, Rui Leonardo Maia (Eds): "Special Education: From Theory to Practice" (pp. 513-520). PragaPortugal: Universidade Fernando Pessoa editions

McDougall, J., De Wit, D. J., King, G., Miller, L. T., \& Killip, S. (2004). High school-aged youth's attitudes toward their peers with disabilities: The role of school and student interpersonal factors. International Journal of Disability, Development and Education, 51, 287-313

Moore, D., \& Nettelbeck, T. (2013). Effects of short-term disability awareness training on attitudes of adolescent schoolboys toward persons with a disability. Journal of Intellectual and Developmental Disability, 38(3), 223-231

Morin, D., Rivard, M., Crocker, A., Boursier, C., \& Caron, J. (2013). Public Attitudes towards Nowicki, E. A., \& Brown, J. D. (2013). "A Kid Way": Strategies for Including Classmates With Learning or Intellectual Disabilities. Intellectual \& Developmental Disabilities, 51(4), 253-262
O'Connor, E. (2016). The use of 'Circle of Friends' strategy to improve social interactions and social acceptance: a case study of a child with Asperger's Syndrome and other associated needs. Support For Learning, 31(2), 138-147.

O'Neill, B. E. (2013). Improvisational play interventions: Fostering social-emotional development in inclusive classrooms. YC Young Children, 68(3), 62

Osborne, A.G.Jr. (2008). Inclusion. In C. J. Russo (Ed.), Encyclopedia of Edu-cation Law (Vol. 1, 458-459). Thousand Oaks, CA: SAGE Publications.

Price, C. L., Ostrosky, M. M., \& Santos, R. M. (2016). Reflecting on Books That Include Characters With Disabilities. YC: Young Children, 71(2), 30-37.

Ranson, N. J. and Byrne, M. K. (2014) 'Promoting Peer Acceptance of Females with Higher-functioning Autism in a Mainstream Education Setting: A Replication and Extension of the Effects of an Autism AntiStigma Program', Journal autism Developmental Disorder. 44, pp. 2778-2796.

Rillotta, F. and Nettelbeck, T. E. D. (2007) 'Effects of an awareness program on attitudes of students without an intellectual disability towards persons with an intellectual disability', Journal of Intellectual \& Developmental Disability, 32(1): 19-27

Roberts, C. \& Zubrick, S. 1992. Factors influencing the social status of children with mild academic disabilities in regular education classrooms. Exceptional Children, 59(3), 192202.

Salend,S.J. \& Duhaney, L.M.G (1999). The Impact of Inclusion on Students With and Without Disabilities and Their Educators. Remedial and Special Education Vol 20(2). 114-126

Seidler, C. O. (2011). Fighting Disability Stereotypes with Comics: "I Cannot See You, But I Know You Are Staring at Me". Art Education, 64(6), 20-23

Sheehy, K. \& Budiyanto. (2015) 'The Pedagogic Beliefs of Indonesian Teachers in Inclusive Schools', International Journal of Disability, Development and Education, 62(5), pp. $469-485$.

Sigmon, M. L., Tackett, M. E., \& Azano, A. P. (2016). Using children's picture books about autism as resources in inclusive classrooms. The Reading Teacher, 70(1), 111-117. 
Tempo.co. (2017, 22 September). Sarana Pendidikan Inklusif Harus Diperluas diperoleh https://nasional.tempo.co/read/911696/saranapendidikan-inklusif-harus-diperluas

Tindall, D. (2013). Creating disability awareness through sport: exploring the participation, attitudes and perceptions of postprimary female students in Ireland. Irish Educational Studies, 32(4), 457-475.

Tkachyk, R. E. (2013). Questioning secondary inclusive education: Are inclusive classrooms always best for students?. Interchange, 44(1-2), 15-24.

Wilkins, J., Howe, K., Seiloff, M., Rowan, S., \& Lilly, E. (2016). Exploring elementary students' perceptions of disabilities using children's literature. British Journal of Special Education, 43(3), 233-249

Williamson, C. (2014). Effects of Disability Awareness Educational Programs on an Inclusive Classroom Honors Projects. Paper 134.

Yu, S; Ostrosky, M.M; Fowler, S. A. (2012) 'Measuring Young Children's s Attitudes Toward Peers With Disabilities Measuring Young Children' s Attitudes Toward Peers With Disabilities: Highlights From the Research', Topics in Early Childhood Special Education, 32(3), pp. 132-142. 